\title{
COWS' MILK INTOLERANCE
}

\section{ANNE FERGUSON AND KAREN C. WATRET}

Gastrointestinal Unit, Western General Hospital and University of Edinburgh, Edinburgh

\section{CONTENTS}

INTRODUCTION . . . . . . . . . . . . . 2

FOOD INTOLERANCE AND RELATED DISORDERS . . . . . . 2

DEFINITIONS AND CLINICAL SPECTRUM OF FOOD INTOLERANCF. . . 2

DEFINITIONS OF FOOD-RELATED DISORDERS . . . . . . . . . . . . 3

SYMPTOMS, SYNDROMES AND DISEASES OF FOOD INTOLERANCE . . . . 3

Food intolerance in children. . . . . . . . . . . . . . . . . . 4

Food intolerance in adults . . . . . . . . . . . . . . . . . 4

Food aversion . . . . . . . . . . . . . . . 4

Prevalence of food intolerance $\quad . \quad$.

APPROACHES TO DIETARY TREATMENT . . . . . . . . . . . 5

IMPORTANCE OF MILK AND MILK PRODUCTS IN FOOD INTOLERANCE • 5

IMMUNOLOGICAL ASPECTS OF THE PROTEINS OF COWS' MILK . 5

PATTERNS OF ANTIBODY RESPONSES TO COWS'-MILK PROTEIN IN MAN * 6

IMMUNOGENICITY AND IMMUNOLOGICAL CROSS-RFACTIVITY OF COWS'-

MILK PROTEINS . . . . . . . . . . . . . . . 7

IMMUNE RESPONSES TO MILK PROTEINS FNCOUNTERED VIA THE GUT • 8

MUCOSAL HYPERSENSITIVITY REACTIONS . . . . . . . . . . . . . . . . 9

IMMUNE-ASSOCIATED DISEASES DUE TO MILK INTOLERANCE • 10

ATOPIC ECZEMA . . . . . . . . . . . . . . . . 10

ASTHMA . . . . . . . . . . . . . . . . . 11

MALABSORPTION SYNDROME WITH COWS'-MILK INTOLERANCE . . $\quad 12$

COWS'-MILK-SENSITIVE COLITIS . . . . . . . . . . . . . . . 13

INFANTILE COLIC . . . . . . . . . . . . . . . . . . . 14

LACTOSE INTOLERANCE . . . . . . . . . . . . . . . . . . 14

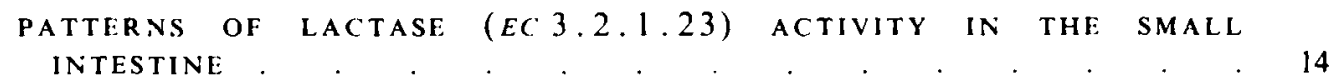

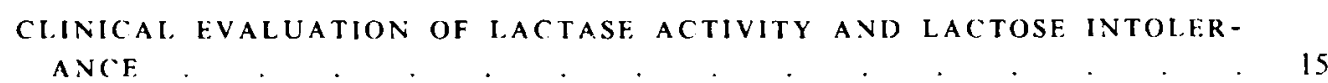

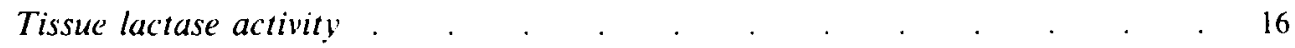

Lactose tolerance test . . . . . . . . . . . . . . . . . . . . . . 16

Lactose malabsorption: reducing substances in stools . . . . . . . . . 16

Lactose malabsorption: breath tests . . . . . . . . . . . 16

Clinical lactose intolerance . . . . . . . . . . . . . . . . . . 16

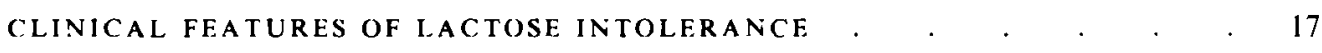


CLINICAL SYNDROMES OF LACTOSE INTOLERANCE .

Modification of milk-drinking habits

Irritable bowel syndrome

Diarrhoea after gastric surgery . . . . . . . . . . . . . . 18

Multiple pathology

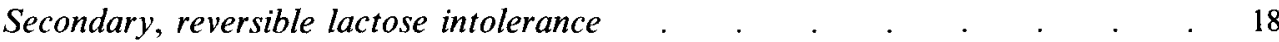

TREATMENT OF LACTOSE INTOLERANCE . . . . . . . . . . . . 19

\section{INTRODUCTION}

Intolerance to ingested cows' milk has several quite different mechanisms, involving various constituents of milk. In order to provide a proper perspective on the subject, the present review begins with a section on food intolerance in general; since allergic, immunological reactions are the cause of several of the diseases to be discussed, there follows an outline of immunogenicity of and immunological reactions to cows'-milk-protein antigens. In the second half of the review, the specific diseases and syndromes are considered.

\section{FOOD INTOLERANCE AND RELATED DISORDERS}

\section{DEFINITIONS AND CLINICAL SPECTRUM OF FOOD INTOLERANCE}

All of us have experienced adverse reactions to ingested foods. The clinical manifestations may be merely abdominal discomfort or perceived changes in gut physiology; or there may be significant symptoms, strongly suggestive of disease. In some individuals, adverse reaction to food is the pathogenesis of their illness, for example, the gluten-sensitive enteropathy of coeliac disease.

Public interest in diet and nutrition, and the current trend towards a higher-fibre lowerfat diet, have been generally welcomed by health professionals. Unfortunately there has been a parallel public concern, probably unwarranted but greatly fuelled by the media, that reaction to foods, food additives, beverages and even water, cause a wide range of distressing physical and psychological problems and chronic, disabling diseases (for review, see Barnetson \& Lessof, 1983). A considerable amount of relevant research has been undertaken and reported in the medical and scientific press, there have been considerable advances in the understanding of immunological and pharmacological mechanisms of food intolerance, and psychologically-based reactions to foods have been clearly defined. In addition to the many books, symposia and journal supplements devoted to the topics of food allergy and intolerance, there has been a series of authoritative monographs from both sides of the Atlantic.

A European Economic Community (EEC) Scientific Committee for Food considered the problem of sensitivity to food ingredients and additives, and the report was published the following year (Commission of the European Communities, 1980). It contained a useful list of definitions, recommended appropriate labelling of foods and identified the need to develop better tests of the allergenic potential of substances incorporated in the diet. Three years later, in the report of a joint working party of the Royal College of Physicians and the British Nutrition Foundation (Joint Report) (1984), the definitions of food-related diseases were expanded to include an important group of patients seen in clinical practice, who have no evidence of organic disease (see p. 3). 
A monograph from the American Academy of Allergy and Immunology and National Institute of Allergy and Infectious Diseases (1984) gives an excellent account of the trulyallergic phenomena relevant to foods and in an appendix almost 400 diseases transmitted by foods are listed and classified. A number of other aspects of adverse reactions to foods and food additives are covered in a supplement to the Journal of Allergy and Clinical Immunology (Metcalfe, 1986). For example, in a nationwide study of 200 middle-class women conducted by the Good Housekeeping Institute, $30 \%$ of the women interviewed reported that they or some member of their family had allergy to a food product, and in $19 \%$ of families one or more family members was on a special diet because of food allergies. Dr Charles May, whose clinic in Denver was a model for the objective diagnosis and longterm management of food intolerance, describes the background of the conflict between the orthodox and unorthodox view of food sensitivity (May, 1986). He warns against "unwarranted confidence in clinical impressions... coupled with faulty diagnostic techniques in the evaluation of highly subjective complaints... bias and prejudice were not excluded in reaching opinions ... hypotheses have not been tested with adequately controlled experiments'. The public should be reassured that the widely-publicized, unorthodox ideas of food allergy have been given full and sympathetic hearings, but have been found wanting.

\section{DEFINITIONS OF FOOD-RELATED DISORDERS}

One of the most important sections of the report of the joint working party on food intolerance of the Royal College of Physicians and the British Nutrition Foundation (Joint Report) (1984) deals with definitions of diseases, and with mechanisms. Two main conditions can be identified, and it is recommended that the terms 'food intolerance' and 'food aversion' are used, and defined as follows:

Food intolerance is a reproducible, unpleasant (i.e. adverse) reaction to a specific food or food ingredient and is neither immunologically nor psychologically based. This reaction occurs even when the affected person cannot identify the type of food which has been given (for example, when it is disguised by flavouring and given as a puree).

Food allergy is a form of food intolerance where there is both a reproducible food intolerance and evidence of an abnormal immunological reaction to the food.

Food aversion comprises both psychological avoidance, when the subject avoids food for psychological reasons, and psychological intolerance, which is an unpleasant bodily reaction caused by emotions associated with food rather than the food itself and does not occur when the food is given in an unrecognizable form.

In those who have reproducible adverse reactions to food due to causes other than food aversion or allergy, various mechanisms may be responsible, including (1) lack of a particular enzyme, e.g., alactasia; (2) a pharmacological effect, e.g., due to caffeine; (3) a histamine-releasing effect in unsensitized individuals, e.g., after consumption of shellfish; (4) an irritant effect on the mucous membranes, e.g., in oesophagitis; (5) gas production and colic due to fermentation of unabsorbed food residues in the colon.

\section{SYMPTOMS, SYNDROMES AND DISEASES OF FOOD INTOLERANCE}

Food aversion, intolerance and allergy are very difficult to distinguish from one another. Whether objective changes are present or not, in most instances the clinical diagnosis of food intolerance can only be established if the symptoms and signs disappear with an elimination diet and if a controlled challenge then leads either to a recurrence of symptoms or to some other clearly identified change-for example, in a jejunal biopsy. 


\section{Food intolerance in children}

In childhood, a wide range of conditions has been associated with food intolerance and includes eczema, wheeze, urticaria, mood alterations, angio-oedema, epilepsy, failure to thrive, diarrhoea, vomiting and gastrointestinal blood loss. The evidence linking hyperactivity to food intolerance is poor, despite some claims to the contrary. Foodinduced colitis differs from ulcerative colitis in many clinical and pathological features. Small-intestinal-mucosa damage with malabsorption is best documented for cows'-milkprotein intolerance, but can also occur with soya-bean, chicken, rice, fish and egg intolerance. These immune-mediated forms of milk intolerance are discussed later (p. 10), as is lactose intolerance.

\section{Food intolerance in adults}

In adults, classical allergic symptoms, urticaria, asthma or anaphylaxis, may be present. Urticaria may be associated with intolerance to food additives via prostaglandin release rather than allergy. The relationship of food to migraine is complex and is likely to have a pharmacological rather than an allergic basis. There are a number of anecdotal claims of an association between food allergy and arthritis but there is little evidence for this which could stand up to critical examination. Psychiatric symptoms such as irritability and depression may accompany other manifestations of food intolerance but it remains to be established whether foods alone can provoke psychiatric disease.

Other food-provoked symptoms are gastrointestinal and include nausea, bloating, abdominal pain, constipation and diarrhoea. These features are identical to those of the irritable bowel syndrome and are also experienced by some patients with lactose intolerance. Indeed, all these conditions may co-exist. In an atopic individual, immediate hypersensitivity can produce pyloric spasm, intestinal hypermotility, oedema with increased secretion of mucus, rectal spasm. The clinical effects include nausea, vomiting, abdominal pain and diarrhoea, anaphylaxis or angio-oedema and in such patients the basis for the symptoms is truly allergic.

\section{Food aversion}

Psychological aspects of food intolerance are fascinating but beyond the scope of the present review. Dieting, over-eating and food fads are extremely common. Among those claiming to have food allergic disorders there are significant numbers of patients who have a personality disorder or are psychiatrically ill and who may respond to psychiatric treatment.

\section{Prevalence of food intolerance}

The incidence and prevalence of food intolerance are unknown. Informed medical opinion is that when lactose intolerance is excluded, the incidence of other conditions is probably less than $1 \%$ with a relatively-higher proportion of allergic food intolerance in infants (Royal College of Physicians and the British Nutrition Foundation (Joint Report) 1984). However, in a community survey of a small South Wales town, 475 subjects responded to a questionnaire (Burr \& Merrett, 1983). Adverse reactions to one or more foods were reported by $19 \%$ of men and $20 \%$ of women. There was no correlation between reported food intolerance and an allergic history or plasma IgE level. 
Table 1. Examples of types of intolerance to cows' milk

\begin{tabular}{ll}
\hline Postulated mechanism & Disease \\
\hline Allergic & Cows'-milk-sensitive enteropathy \\
Enzyme deficiency & Milk-sensitive colitis (infants) \\
'Irritant' & Lactose intolerance \\
Uncertain & Fat intolerance (e.g., biliary colic) \\
Aversion & Diarrhoea (normal lactase) \\
Contamination-infection & Distaste, avoidance \\
\hline
\end{tabular}

\section{APPROACHES TO DIETARY TREATMENT}

There are two patterns. The symptoms and clinical features may conform to wellrecognized phenomena or to a disease associated with a specific food. This will be suspected from the history and confirmed by a small number of tests. Examples include asthma, rhinitis and eosinophilia associated with salicylate intolerance; flatus and diarrhoea induced by sorbitol from diabetic foods; an increase in milk consumption unmasking a previously - asymptomatic lactose intolerance; coeliac disease presenting in an anaemic child with failure to thrive and a positive family history.

In other patients, food intolerance will be included in a wider differential diagnosis. When symptoms are mild, simple symptomatic treatment may be more appropriate initially than diagnostic and therapeutic diets, which tend to be time-consuming and difficult. If food intolerance is to be pursued, a baseline elimination diet is taken for some weeks; if symptoms and signs disappear, relevant foods are identified during a planned period of reintroduction, and confirmed by placebo-controlled challenges if feasible.

\section{IMPORTANCE OF MILK AND MILK PRODUCTS IN FOOD INTOLERANCE}

Examples of virtually all the known mechanisms of food intolerance can be provided, in which milk or milk products are the culprits. Some examples are listed in Table 1 and the more important conditions are discussed later in more detail (pp. 10-14). On a global scale, acquired adult lactose intolerance outnumbers all other forms of food intolerance. The many other examples of milk intolerance provide a wide spectrum of clinical severity and diagnostic challenge. Vigilance by farmers and the dairy industry, should virtually eliminate risks of milk-related infection. Flavouring agents, colours, preservatives, emulsifiers and other additives are present in some milk products, greatly extending the potential mechanisms of intolerance. Finally, milk is often combined with other nutrients in processed foods, with implications for the dietary management of milk-protein intolerance. Information on foods which contain milk proteins is available to doctors and dieticians in the UK, from the Food Intolerance Databank at the Leatherhead Food Research Association.

\section{IMMUNOLOGICAL ASPECTS OF THE PROTEINS OF COWS' MILK}

Whole cows' milk contains some $3.3 \mathrm{~g}$ protein $/ \mathrm{ml}, 80 \%$ of which is casein, $20 \%$ whey. There are four major bovine caseins, alpha, beta, gamma and kappa with molecular 
weights ranging between 18000 and $24000 \mathrm{Da}$. Beta-lactoglobulin (BLG) is the major whey protein, composed of two identical polypeptide chains each having a molecular weight of about $18000 \mathrm{Da}$. Concentration of BLG in skimmmed milk is about $2-3 \mathrm{~g} / 1$. Alphalactalbumen (ALA) comprises a single polypeptide chain, molecular weight about 15000 $\mathrm{Da}$ and is present at a concentration of about $1 \mathrm{~g} / \mathrm{l}$ skimmed milk. In addition, bovine milk contains a range of bovine serum proteins including bovine serum albumin (BSA) and bovine immunoglobulins (bovine gamma-globulins; BGG).

Antigens of cows' milk which induce hypersensitivity reactions are confined to the protein components. Neither milk fat nor lactose is antigenic, although there is an interesting report (Spies, 1971) that commercial preparations of lactose, as are used in clinical challenge tests, may contain small amounts of milk proteins. The allergenicity (capacity to induce immune responses, see p. 000) of cows'-milk proteins is enhanced by a Maillard reaction with lactose which results in $n$-glycosidic coupling of the sugar into the protein molecule. Fir example, Bleumink \& Young (1968) showed in atopic persons with milk hypersensitivity that the skin reactivity to BLG was increased 100 -fold by previous reaction of the prot in with lactose.

On the other hand, digestion of milk proteins may reveal new immunogenic epitopes which are not present on the intact molecule. This has been studied in man for IgE responses to BLG degradation products (Schwartz et al. 1980), and in an animal model new amino acid sequences were revealed during digestion of BSA, and these induced quite distinct patterns of immune responses when compared with the native protein (Michael et al. 1981).

In clinical studies particular attention has been paid to BLG, but reactions to all the milk proteins may occur. For example, Goldman et al. (1963) orally challenged a group of children with cows'-milk allergy; $62 \%$ reacted with BLG, but in addition $60 \%$ reacted with casein, $53 \%$ with ALA and $52 \%$ with BSA. Lebenthal (1975) reviewed the results of five studies and pointed out that sensitivity to BLG occurred in $82 \%$ of patients, to casein in $43 \%$, to ALA in $41 \%$, to BGG in $27 \%$ and to BSA in $18 \%$.

\section{PATTERNS OF ANTIBODY RESPONSES TO COWS'-MILK PROTEIN IN MAN}

There have been many reports, using a wide range of techniques, of the titres and patterns of antibodies to cows'-milk proteins in the serum of human infants and children. For example May et al. (1977) used a protein-binding technique to detect and measure antibodies to BSA, casein, ALA, BLG and BGG in infants and children who were not hypersensitive to foods. They found antibodies in the serum of a proportion of children up to 15 years of age to all these antigens, but antigen binding capacity of serum was distinctly higher in the first year of life. In the 1970 s we used passive haemagglutination and precipitin tests in the clinical immunology laboratory in Glasgow, and found that serum antibodies to all five major proteins were present in more than $50 \%$ of children aged under 4 years. Titres, and proportion of children with detectable antibody, fell in older children and few healthy adults (e.g., blood donors) have circulating antibodies to milk. Children with diffuse small bowel disease and enhanced intestinal permeability, such as in coeliac disease, tend to have high titres of serum antibody to many foods, but we found that the distribution of antibody to the various milk proteins was similar in coeliac and other children (A. Ferguson, unpublished results).

$\mathrm{IgE}$ responses to food proteins are of greater relevance than other isotypes as the mechanism of food allergic disease. The development of such antibodies in a group of eighty-six normal female infants followed from birth to 7 years of age has been reported 


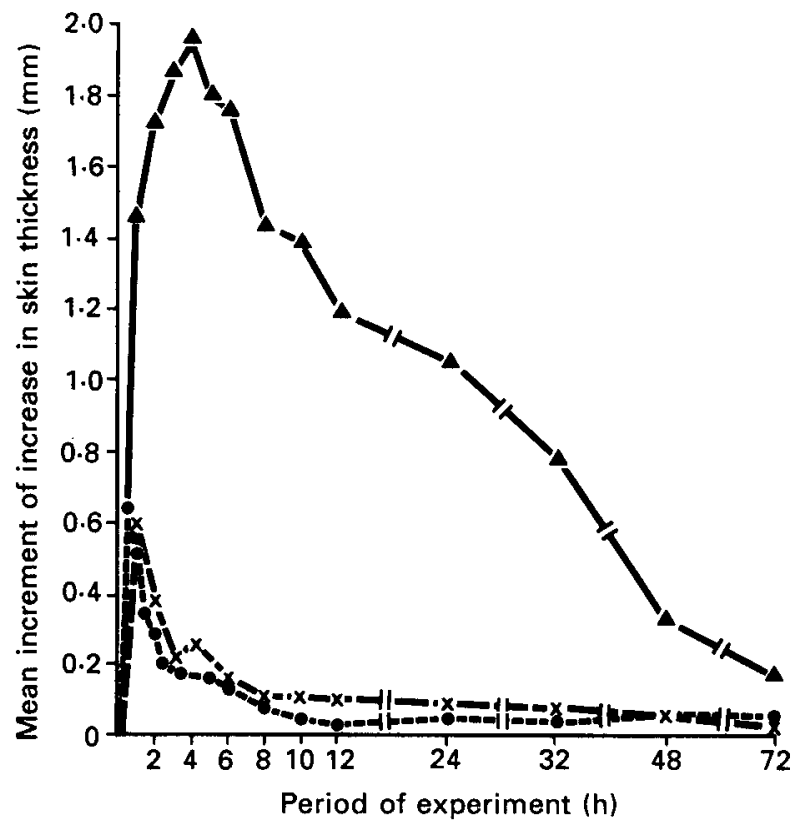

Fig. 1. Absence of in vivo reactivity to the milk protein bovine serum albumin (BSA) in T-cell-depleted mice. (A), Normal mice (BSA in complete Freund's adjuvant (CFA); $(x)$, thymus-deprived mice (BSA in CFA); (O), saline ( $9 \mathrm{~g}$ sodium chloride/1) control. Mice were immunized with BSA in CFA and the increase in footpad thickness measured at time-intervals indicated. The absence of reactivity in the $T$ cell-depleted mice illustrates the necessity for immunoregulatory $T$ cells in the induction of an immune response.

(Hattevig et al. 1984, 1987) ; 15\% of the infants were atopic but no child was allergic to milk by the age of 7 years. Transient IgE antibodies to food proteins were detected in a proportion of the children, and at 7 years of age seven of the eighty-six children had detectable, although still low, amounts of IgE antibodies to cows' milk. Phadebas (Pharmacia Diagnostics, Uppsala, Sweden) continue to recommend whole milk as the best available preparation for in vitro detection of $\operatorname{IgE}$ antibodies to milk proteins.

\section{IMMUNOGENICITY AND IMMUNOLOGICAL CROSS-REACTIVITY OF COWS'-MILK PROTEINS}

Relatively simple immunological techniques can provide a great deal of information on epitopes (antibody-combining sites) of complex molecules such as the milk proteins. A naive animal is given one or more injections of test substance without adjuvant (or alternatively the substance can be administered by feeding, but this raises serum antibodies predictably only in the rabbit and guinea-pig). At a later date immunological responsiveness of the animal to the same or potentially cross-reacting proteins can be assessed by studies of serum antibodies, by skin tests, by ingestion or inhalation challenges, or by in vitro tests on lymphoid cells retrieved from spleen, blood or lymph nodes. Fig. 1 illustrates the results of in vivo skin testing in mice immunized with the milk-protein BSA. The absence of in vivo reactivity in an immunized, T-cell-depleted mouse (thymectomized, irradiated and bonemarrow reconstituted) illustrates the point that both antibody-producing B-cells, and immunoregulatory $\mathrm{T}$-helper cells are necessary for the orderly induction of an immune response. 
Table 2. Immunogenicity and immunological cross-reactivity of foods and food proteins

\begin{tabular}{|c|c|c|c|c|}
\hline \multirow[b]{2}{*}{$\begin{array}{l}\text { Rats immunized } \\
\text { with }\end{array}$} & \multicolumn{4}{|c|}{ Precipitin reaction of rat serum with: } \\
\hline & $\begin{array}{c}\text { Defatted } \\
\text { cows' milk }\end{array}$ & Vivonex & $\begin{array}{l}\text { Elemental } \\
028\end{array}$ & Maxipro \\
\hline Maxipro* & + & - & - & + \\
\hline Enteral $400^{*}$ & + & - & - & + \\
\hline Elemental $028 \uparrow$ & - & - & - & - \\
\hline Vivonext & - & - & - & - \\
\hline
\end{tabular}

+ , Positive; --, negative.

* Contains whey proteins; Scientific Hospital Supplies Ltd, Liverpool.

$\dagger$ Manufacturers claim these are elemental and non-allergenic; confirmed by in vivo testing. Elemental 028 was supplied by Scientific Hospital Supplies Ltd and Vivonex by Norwich Eaton Ltd, Newcastle-upon-Tyne.

Chemically defined diets are useful in the elimination diet phase of diagnosis of food intolerance. Elemental and other liquid diets are also used in the management of patients with inflammatory bowel disease. Since some of these products are derived from whey protein, we have examined those used in our clinical practice for the presence of immunoreactive milk proteins. Adult rats were immunized with $500 \mu \mathrm{g}$ protein (or protein equivalent) in Complete Freund's adjuvant (CFA) at 0 and 4 weeks, then bled out by cardiac puncture at 8 weeks. Microprecipitin tests in agarose were used, in various combinations of antigen and test serum, to establish whether immunization with milk proteins induces serum antibodies to the test diets, or vice versa. Some examples are listed in Table 2. Galant et al. (1977) immunized rabbits with Vivonex, milk or egg, then tested for serum antibodies by precipitin and passive cutaneous anaphylaxis techniques. They also showed that the elemental diet Vivonex was not immunogenic.

An in vivo oral screening procedure was used by Coombs and colleagues (McLaughlan et al. $1981 a, b)$ in guinea-pigs to evaluate reduction in allergic potency of milk substitutes intended for infant feeding. Guinea-pigs were allowed to drink pasteurized milk for 1 week. After a further $7 \mathrm{~d}$ all demonstrated an anaphylactic sensitivity when $0.5 \mathrm{ml}$ skimmed milk was injected intravenously. Ingestion of evaporated milk rather than pasteurized milk led to a significantly reduced anaphylactic sensitization, and severe heat treatment of milk reduced its capacity to sensitize guinea-pigs when administered orally. Infant formulas based on hydrolysed casein or hydrolysed whey failed to induce sensitization in guinea-pigs (Granati et al. 1985; Pahud et al. 1985). However, Kilshaw et al. (1982) found that extensive heat denaturation of whey proteins also destroyed some vitamins. Nutritional quality must be considered in addition to immunogenicity in attempts to produce so-called hypoallergenic milk formulas.

Poulson et al. (1987) investigated mice in more detail. Mice were sensitized by oral or subcutaneous immunizations with various types of bovine milk and were challenged intravenously with diluted milk samples. They found that pasteurization did not change the ability of milk to induce anaphylactic shock.

\section{IMMUNE RESPONSES TO MILK PROTEINS ENCOUNTERED VIA THE GUT}

When antigen is introduced into the tissues of an animal a variety of immune responses may be evoked, and these are not mutually exclusive. In the case of antigen normally 
Table 3. Dose-dependent suppression of subsequent systemic immune responses of $B D F_{1}$ mice by previous feeding of antigen (beta-lactoglobulin; $B L G$ )

(Mice were fed on BLG or saline $(9 \mathrm{~g}$ sodium chloride/l) on day 0 , then all were immunized with BLG in complete Freund's adjuvant (CFA) on day 7. After 3 weeks serum antibodies were measured by enzyme-linked immunosorbent assay, and delayed type hypersensitivity by a footpad-swelling test. Only the previous feed of $50 \mathrm{mg}$ BLG gave suppression of subsequent systemic immune responses, oral tolerance).

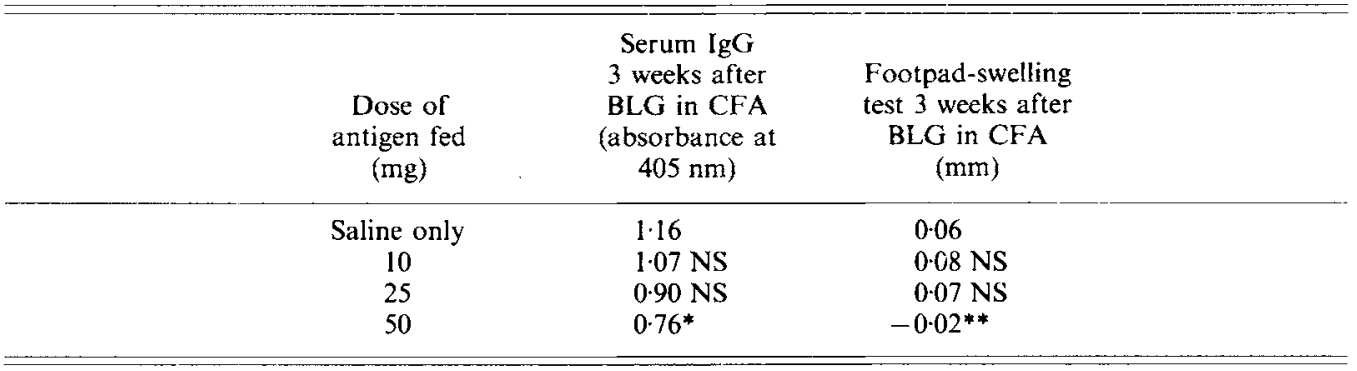

NS, not significant.

Significantly different from saline: ${ }^{*} P<0.05,{ }^{* *} P<0.01$.

encountered via the gut it is relatively unusual for there to be induction of a serum antibody response (the guinea-pig being an exception to this rule), and the most striking effects are induction of mucosal IgA antibodies, and suppression of systemic immune responsiveness, oral tolerance. Active immune responses can readily be detected and measured in humans as well as in animals, whereas the phenomenon of immunological tolerance to ingested protein is best demonstrated in experimental animals. We are currently examining immune responses to BLG in mice.

As described previously, for evaluation of active systemic immunity animals are immunized with antigen in CFA. After 3 weeks serum antibody responses are measured by an enzyme-linked immunosorbent assay and delayed type hypersensitivity (DTH) by an in vivo skin test. If, before systemic immunization, mice are given a single feed of BLG, there is dose-dependent suppression of systemic immune responsiveness (Table 3). Tolerance is a most important protective, homeostatic function of the gut-associated lymphoid tissues and its induction is probably the most important factor preventing development of food allergy in animals as well as man.

\section{MUCOSAL HYPERSENSITIVITY REACTIONS}

When oral tolerance fails and a state of active systemic immunity is induced, re-exposure to antigen is likely to produce intestinal and systemic hypersensitivity reactions analogous to those experienced in clinical food allergy. The cows'-milk protein BSA and the hens'-egg protein ovalbumin (OVA) have been extensively used in investigation of the induction and expression of intestinal anaphylaxis (for review, see Ferguson, 1987). Granato \& Piguet (1986) succeeded in producing a monoclonal IgE antibody directed against bovine BLG. They found that $1 \mathrm{ng}$ of this purified antibody was capable of eliciting cutaneous anaphylaxis and demonstrated very clearly the development of an immediate hypersensitivity reaction to BLG within the gut in passively immunized mice fed on BLG. Fluid accumulation within the small intestinal lumen, increased permeability of the gut, and oedema within the villi were present at $30 \mathrm{~min}$ after the challenge feed. Studies in this and 
Table 4. Effects of intestinal anaphylaxis on small intestinal structure and function in the rat (from Perdue et al. 1984)

\begin{tabular}{|c|c|c|c|c|c|}
\hline & \multicolumn{4}{|c|}{ Gut loop perfused with } & \multirow{3}{*}{$\begin{array}{c}\text { Statistical } \\
\text { significance of } \\
\text { difference between } \\
\text { control and } \\
\text { antigen perfusion }\end{array}$} \\
\hline & \multicolumn{2}{|c|}{ Control solution } & \multicolumn{2}{|c|}{ Antigen (OVA) } & \\
\hline & Mean & SE & Mean & SE & \\
\hline Villus height $(\mu \mathrm{M})$ & 321 & 20 & 305 & 34 & NS \\
\hline Crypt length $(\mu \mathrm{M})$ & 139 & 8 & 146 & 13 & NS \\
\hline $\begin{array}{l}\text { Mast cell count (in nine villus-crypt } \\
\text { units) }\end{array}$ & 41 & 3 & 25 & 2 & $P<0.001$ \\
\hline $\begin{array}{l}\text { Absorption of water and electrolytes } \\
\text { from perfusate }\end{array}$ & $\begin{array}{l}\text { After } 40 \\
\text { absorpti } \\
\text { significar }\end{array}$ & $\begin{array}{l}\text { ferfusio } \\
\text { f water } \\
\text { less tha }\end{array}$ & $\begin{array}{l}\text { ith antig } \\
+, \mathbf{K}^{+}, \mathbf{C} \\
\text { control }\end{array}$ & $\begin{array}{l}\text { net } \\
\text { eriment }\end{array}$ & $P<0.01$ \\
\hline $\begin{array}{l}\text { Histamine content in mucosal } \\
\text { homogenates }(\mathrm{ng} / \mathrm{mg} \text { protein) }\end{array}$ & 3.67 & $1 \cdot 04$ & 0.58 & 13 & $P<0.005$ \\
\hline $\begin{array}{l}\text { Histamine and protein content of } \\
\text { perfusate }\end{array}$ & Significan & igher $\mathrm{tl}$ & controls & & $\begin{array}{l}P<0.05 \text { and } \\
P<0.025\end{array}$ \\
\hline \multicolumn{6}{|l|}{$\begin{array}{l}\text { Enzyme activities of mucosal } \\
\text { homogenates: }\end{array}$} \\
\hline Sucrase (EC 3.2.1.48) & $95 \cdot 8$ & $4 \cdot 6$ & $77 \cdot 3$ & $5 \cdot 1$ & $P<0.025$ \\
\hline Na,K-ATPase (EC 3.6.1.8) & $140 \cdot 3$ & $14 \cdot 2$ & 117 & $12 \cdot 2$ & NS \\
\hline Thymidine kinase $(E C 2.7 .1 .21)$ & $3 \cdot 1$ & 0.2 & $5 \cdot 0$ & 0.7 & NS \\
\hline Alkaline phosphatase (EC 3.1 .3 .1 ) & $4 \cdot 0$ & $0 \cdot 6$ & $3 \cdot 6$ & $0 \cdot 2$ & NS \\
\hline
\end{tabular}

NS, not significant; OVA, ovalbumin.

similar animal models (Table 4) fully support the descriptions of the clinical and pathological effects of intestinal anaphylaxis in half a century of the biomedical literature.

IgE-mediated hypersensitivity reactions produce oedema, diarrhoea and functional changes in epithelial fluid and electrolyte transport without any histological changes or malabsorption. There is a wealth of evidence, based on animal work, that it is the T-cellmediated reactions in small bowel mucosa which cause immune-mediated villus atrophy, crypt hyperplasia with malabsorption (Table 5) (for review, see Ferguson, 1987). To our knowledge there have been no studies of animal models of cell mediated immune responses to cows' milk proteins in the gut mucosa.

\section{IMMUNE-ASSOCIATED DISEASES DUE TO MILK INTOLERANCE}

\section{ATOPIC ECZEMA}

The incidence of atopic eczema is rising in Britain and, although the pathogenesis has not been clearly established, foods are implicated among the environmental factors leading to induction of and exacerbation of this distressing skin disease (Atherton, 1983).

The strongest evidence of a role for diet in the management of atopic eczema is the outcome of a trial in which thirty-six children with atopic eczema, aged 2-8 years, were entered into a 12-week double-blind controlled crossover trial of an egg and cows'-milk exclusion diet (Atherton et al. 1978). Twenty children finished the study. Fourteen patients responded to the antigen-avoidance diet whereas only one responded to the control diet which contained egg and cows' milk. Interestingly, there was no correlation between 
Table 5. Effects of delayed type hypersensitivity reactions in the jejunal mucosa of rodents (for review, see Ferguson, 1987)

\author{
Crypt hyperplasia \\ Villus atrophy \\ Brush border enzyme deficiency \\ Malabsorption (carbohydrate) \\ Rise in intraepithelial lymphocyte count \\ Mitosis of intraepithelial lymphocytes \\ Expression of Class II histocompatibility antigens by crypt enterocytes
}

positive skin-prick tests to egg and cows' milk and response to the trial diet, suggesting that factors other than merely IgE antibody were likely to be implicated.

Eczema can occur in exclusively breast-fed infants, but this can be due to the carry-over of food antigens in the mother's milk. Cant et al. (1985) examined eczematous infants and controls by skin-prick tests to individual food and inhalant antigens. Although skin-prick test reactions for foods are not fully reliable, it was striking that eleven of thirty-four infants with possible or definite atopic eczema had strongly positive skin-test reactions to egg and five of them had strongly positive reactions to cows' milk, whereas none of thirty-four controls had such skin-test reactivity.

The important phenomenon of oral tolerance was mentioned previously in the section on immunogenicity of milk proteins. It is not known whether the immune status of mothers, sensitized or tolerant, can be transferred to infants, or whether any transfer of specific immune reactivity (other than IgG) of infants is due to transplacental or transmammary antigen passage. A number of ambitious, long-term studies are in progress in several countries, examining the possible beneficial effects of maternal antigen elimination during and after pregnancy, in attempts to delay or prevent the development of atopic eczema in infants. Results are at the moment inconclusive, and the best recommendation for the mother of an atopic infant is still to take a healthy mixed diet and to breast feed for 4-6 months. In experimental animals, it is extremely small doses of antigen which tend to induce IgE responses (Jarrett, 1977). Clinical studies, for example, those of Firer et al. (1981), support this concept in human infants, in that small amounts of cows' milk are much-more likely to lead to anaphylactic sensitization of infants than is a full cows'-milkprotein diet. For this reason attempts to reduce the prevalence of allergy and $\operatorname{IgE}$ antibody production to cows'-milk proteins by the use of so-called hypoallergic milks, with low concentrations of milk-protein antigens, is scientifically unsound and should not be encouraged.

Food intolerance and enhanced immune responsiveness to foods is also a feature of atopic eczema in adults. However, the antigens concerned are usually fish, shellfish, eggs and nuts and milk sensitivity does not seem to be an important component of the food allergy associated with adult atopic eczema (Barnetson, 1980; Barnetson et al. 1981).

In contrast to the situation in infants with cows'-milk protein-sensitive enteropathy and failure to thrive (see p. 000), the morphology of the jejunum is only marginally abnormal in children with eczema due to food allergy (McCalla et al. 1980; Perkkio, 1980).

\title{
ASTHMA
}

An excellent and thoughtful appraisal of food sensitivity in childhood asthma was published recently (Wilson \& Silverman, 1985). In a group of hospital-based asthmatic children, at least one item of food was reported as increasing symptoms in twenty-seven of 
forty-four non-Asian children and thirty-one of thirty-four Asian children. A number of other factors accentuated the adverse reaction to food or drink, including exercise, laughter, viral infection, season, weather, temperature of the food as well as the quantity and frequency of ingestion. Eggs and milk were identified as the possible incriminating foods in less than $10 \%$ of the children and this would support clinical observations that milk intolerance does not appear to be an important factor in asthma in childhood, when compared with the less common inhalant allergens.

A limited role for food intolerance in adults with asthma was demonstrated by a doubleblind controlled trial of elemental diet in severe perennial asthma of unknown aetiology (Hoj et al. 1981). There was a statistically significant improvement in various objective features of asthma in the period of treatment with an elemental diet. It was their impression (Hoj et al. 1981) that benzoates, colouring agents and other additives were likely to be more important aetiological factors than specific foods, although they appear to have reached this conclusion on the results of open challenge studies after the trial of elemental diet was completed.

\section{MALABSORPTION SYNDROME WITH COWS'-MILK INTOLERANCE}

In the 1960s there were a number of case reports and individual small studies suggesting that intolerance to cows' milk led to diarrhoea with failure to thrive in infants, and in the next decade several large studies, backed up by histopathological findings, were reported. Kuitunen et al. (1975) published a clinical description of fifty-four infants with malabsorption and cows'-milk intolerance seen during a 10-year period. All had diarrhoea and failure to thrive; in the majority vomiting was also a feature and about $20 \%$ had atopic eczema and recurrent respiratory infections. Gastrointestinal investigations demonstrated malabsorption, and jejunal biopsy revealed abnormalities of the jejunal mucosa, ranging from moderate villus atrophy to a pathology indistinguishable from coeliac disease. The Finnish paediatricians (Kuitunen et al. 1975) treated their patients with human milk and once clinical recovery was complete, patients were challenged with cows' milk. Clinical effects of milk provocation varied. Twenty-eight of the infants had a rapid reaction (gastrointestinal symptoms occurring within $1 \mathrm{~d}$ of the challenge). However, in twenty-six children the response was much slower. In eight children, challenges were also carried out with individual cows'-milk proteins. Five of six responded to casein, one of four to ALA, six of seven to BLG, one of seven to BSA and one of five to BGG. All the children were clinically tolerant of cows' milk by the age of 1 year, although the proximal jejunal mucosa often showed persistent but minor abnormalities.

Fontaine \& Navarro (1975) had very similar findings in thirty-one infants with cows'milk-protein intolerance in whom intestinal biopsies were performed. Mucosal damage was invariably present, with recovery of normal mucosal appearance after a few months treatment with a milk-free diet. Walker-Smith (1975) recommended that histological criteria substitute for the previously recommended clinical 'Goldman' criteria (Goldman et al. 1963) for diagnosing cows'-milk allergy. Goldman's criteria required that symptoms subside after dietary elimination of milk; symptoms recur within $48 \mathrm{~h}$ after milk challenge and reactions to three such challenges must be positive and have a similar onset duration and clinical features (Goldman et al. 1963).

In clinical practice, now that a disease, malabsorption syndrome with cows'-milk-protein tolerance, is fully recognized by paediatricians, there is need for jejunal biopsy in diagnosis, particularly if the condition starts before introduction of gluten into the diet, so that there is no possible confusion with coeliac disease. The need to confirm the existence of the 
condition by challenge when it is normally self limiting, is to be questioned (Sumithran \& Iyngkaran, 1977; Cucchiara et al. 1983).

Typically, a European infant who is subsequently found to have malabsorption with cows'-milk-protein intolerance is atopic and will not have been breast fed. Globally, chronic diarrhoea in infants is usually attributed to infection, but Manuel et al. (1980) report an attempt to establish whether cows'-milk-sensitive enteropathy existed in urban bottle-fed infants in Indonesia. By using serial small-intestinal biopsy related to milk challenge they studied forty-six infants with chronic diarrhoea. Thirty-three had an abnormal small-intestinal mucosa at the time of presentation, twenty improved on a milkfree diet and of these twelve showed an unequivocal histological mucosal relapse after a milk challenge. This theoretically very important observation requires further confirmation since the implications are considerable.

Lactose intolerance is considered separately (p. 14). However, clinical lactose intolerance overlaps with the syndrome of cows'-milk-protein sensitive enteropathy. Where there is extensive villus atrophy, loss of disaccharidase-containing mature enterocytes leads to a relative reduction in the disaccharidase activity of the small-bowel mucosa and thus there may be a reversible lactose intolerance consequent on the enteropathy of cows'-milkprotein intolerance (Harrison et al. 1976; Iyngkaran et al. 1979). The most important practical consequence of this is that lactose intolerance should not be accepted as a primary explanation of malabsorption, failure to thrive etc., but it should be appreciated that it can accompany a number of other more serious enteropathies. Additionally, when milk challenge is to be considered, it is often advisable first to carry out a lactose challenge in the healthy infant on a milk-free diet. When this produces no clinically adverse effect, reactions to cows'-milk challenge can be attributed to the protein constituents rather than the lactose.

\section{COWS'-MILK-SENSITIVE COLITIS}

Rectal bleeding accompanying other features of cows'-milk allergy in infants was recognized many years ago. However, it was only when the bimodal age distribution of children with colitis was recognized that the specific entity of probable allergic infantile colitis was formally documented (Jenkins et al. 1984; Milla, 1984). Typically, an infant with food-sensitive colitis presents before the age of 1 year with loose, mucousy, bloody stools. In a series of sixteen infants, eleven were less than 4 months old, of whom seven were taking cows'-milk protein only and the remaining four were exclusively breast-fed. Elimination diet and challenge procedures, with clinic observation and rectal biopsy have given similar findings to jejunal biopsy in cows'-milk-sensitive malabsorption syndrome. Rectal biopsy pathology differs from classical ulcerative colitis in that there is preservation of crypt architecture with no crypt abscess formation and no depletion of goblet-cell mucus. Additionally, there are substantial numbers of eosinophils and plasma cells in the lamina propria infiltrate. These infants respond well to elimination of cows' milk from their diet or from that of the mother. Severe clinical colitis was induced by challenge in a small number, and it is recommended that challenge should not be used to confirm a diagnosis of foodsensitive colitis. As is the case for food-sensitive enteropathy, most children can tolerate cows' milk by the age of 2 years, and sensitization to other foods such as soya bean can produce an identical clinical picture to milk-sensitive colitis. There is some evidence to support lymphocyte sensitization in the pathogenesis of this condition (Van Sickle et al. 1985). 


\section{INFANTILE COLIC}

Jakobsson \& Lindberg (1978) suggested that exposure to antigens of cows' milk might cause infantile colic in breast-fed infants. They reported that when breast-feeding mothers of nineteen infants with infantile colic eliminated cows'-milk protein from their diets, the colic disappeared promptly in thirteen of nineteen infants. In twelve infants, milk-proteininduced colic was confirmed by dietary challenge of the mother. Subsequently five of the infants were fed on cows' milk and four reacted promptly with colic. It is of considerable interest that three of these infants developed other symptoms of cows'-milk-protein intolerance (skin rash, vomiting, diarrhoea). Recently, further work from the same research group showed that bovine BLG can regularly be detected in human milk by radio-immunoassay (Axelsson et al. 1986). BLG (5-800 $\mu \mathrm{g} / \mathrm{l})$ was found in $40 \%$ of human-milk samples with no true correlation between daily cows'-milk intake and the concentration of BLG. However, there was a correlation with the mothers' atopic status in that six mothers with allergic symptoms all had detectable BLG, whereas only thirteen of nineteen without evidence of allergy were positive.

\section{LACTOSE INTOLERANCE}

\section{PATTERNS OF LACTASE (EC 3.2.1.23) ACTIVITY IN THE SMALL INTESTINE}

Lactase is one of several disaccharidases contained within the brush border of smallintestinal epithelial cells (enterocytes). In human intestine, intestinal lactase activity is detectable in the fetal gut as early as 8 weeks gestation (Lacroix et al. 1984). Small-bowel lactase activity slowly increases as the fetus matures with a rapid increase in activity after 34 weeks gestation (Antonowicz \& Lebenthal, 1977). However, even in premature infants, efficient lactose hydrolytic activity is present in the gut within a few days of birth (Weaver et al. 1986).

In most mammalian infants tissue lactase activity drops sharply after weaning, a biologically appropriate maturation since mammalian milk is the only known source of lactose. The human species is unusual in that in some races intestinal lactase persists into adult life, probably as a result of selective pressures which allow persistence of a mutant gene in certain ethnic groups. Races whose ancestors were Northern European, African pastoralists or residents of the north-western part of the Indian subcontinent have a high probability of retaining intestinal lactase in adult life, whereas most adult Negros, Asians and South Americans are lactose malabsorbers. Population movements in the past hundred years, combined with expansion of the dairy industry beyond temperate zones, mean that many lactase-deficient adults now live in societies where foods which contain lactose are important and regular dietary constituents (Simoons et al. 1977).

It is perhaps remarkable that racial patterns of lactase activity, and associated clinical milk tolerance, have only been recognized for about two decades. Isolated intestinal lactase deficiency in the adult was described by Auricchio et al. (1963) in three patients, two of whom had lactose intolerance precipitated by peptic ulcer surgery. Family studies, carried out on families of lactose-intolerant individuals from populations where lactase persistence into adult life was the norm, suggested a pattern of recessive inheritance of adult-type lactose malabsorption (Ferguson \& Maxwell, 1967; Sahi et al. 1973) and examination of patterns of lactase activity, in the light of proposed gene-dosage effects, confirmed a trimodal distribution in keeping with two populations of homozygotes, for lactase persistence and lactase deficiency in adult life, and one of heterozygotes (Flatz, 1984). Since it is rarely ethical to carry out sequential studies of lactose absorption capacity in normal children, the 
age at which adult-type lactase deficiency develops is uncertain for man. Careful studies in two Finnish boys showed that the period of transition (after age 14 and 9 years respectively when they were still lactose absorbers), was less than 4 years (Sahi \& Launiala, 1977).

Family studies suggest that adult lactase expression is inherited at a single gene locus. Thus, distribution of the genes within a family leads to low lactase activity in homozygotes for lactase absence, intermediate values when one gene for lactase persistence is inherited and high tissue lactase activities when the individual is homozygous for lactase persistence.

Studies of the quantitative distribution of enterocyte enzymes along the villi and crypts of the intestine have shown quite different distribution patterns. In the case of lactase, there is virtually no enzyme activity in crypt enterocytes, enzyme activity increases sharply in the mid-part of the villi with maximal enzyme activity per enterocyte reached apically (Nordstrom \& Dahlqvist, 1973). It appears that protein synthesis begins later for lactase than for some of the other brush border enzymes during cell migration towards the tips of the villi, and this has been suggested as an explanation for the much higher frequency of lactase deficiency in damaged small intestine, when compared with other brush-border enzymes (Rey et al. 1971). However, patterns of lactase activity in relation to epithelial-cellproliferation kinetics have been examined in some detail in a number of experimental and clinical situations, and have failed to confirm the hypothesis that states of accelerated epithelial cell turnover, with presumed immature enterocytes on the villi, produced lactase deficiency (Ferguson et al. 1980). In immune-mediated intestinal injury in neonatal mice, reduction overall in expression of lactase does not exactly correlate with the almost coincident changes in cell proliferation (Lund et al. 1986).

Even in individuals with normal tissue lactase in adult life, or in the preweaning infant, enzyme activity may be reduced when there is disease of the small intestine. Transient lactase deficiency and lactose intolerance are extremely important in diarrhoeal diseases and infections of infants. Because of the relative resistance of the adult intestine to extensive epithelial damage, lactose intolerance secondary to infection, or associated with coeliac disease, is very rarely seen in the adult.

\section{CLINICAL EVALUATION OF LACTASE ACTIVITY AND LACTOSE INTOLERANCE}

In a healthy individual without small bowel disease, a randomly taken mucosal biopsy is, in general, representative of the whole of the intestine and lactase activity in such a specimen gives a good index of the lactase status and lactose-absorptive capacity of that individual. However, in conditions where there is patchy or regional inflammatory change of the intestine, low levels of tissue lactase in a specimen do not necessarily correlate with clinical lactose intolerance, since normal enzyme activity in other, less damaged segments of the intestine can compensate. This was established very clearly in an animal model of rotavirus infection (Ferguson et al. 1981). The capacity for lactose absorption can be evaluated by a number of relatively non-invasive blood or breath tests. Thus several direct and indirect techniques can be used to determine the lactase status of individuals.

On the other hand, lactose intolerance is a clinical phenomenon, usually associated with lactose malabsorption and delivery of unabsorbed carbohydrate into the colon. However, lactose intolerance may be occasionally due to the osmotic effects of a carbohydrate load in the upper small intestine, even in a lactose absorber, e.g., after peptic ulcer surgery. With these definitions borne in mind, a number of clinical investigative techniques are relevant, either in the investigation of an individual patient, or in population studies. 


\section{Tissue lactase activity}

Tissue lactase activity in a jejunal biopsy is the critical investigation, but interpreted in the context of the histopathology of the jejunum. If this is absolutely normal and there is no evidence of other gastrointestinal disease such as coeliac disease, parasite infection, Crohn's disease etc., low tissue lactase activity usually indicates a state of lactose malabsorption. It is also to be emphasized that normal values for tissue lactase activity in the first and second parts of the duodenum are substantially lower than the normal reference values for jejunum.

\section{Lactose tolerance test}

This is the method which was used in the classic early epidemiological studies in North America, Europe and Africa. The profile of blood glucose after an oral loading dose of glucose is compared with the profile of blood glucose after a similar loading dose of lactose. If there are striking differences between the two curves then lactose malabsorption can be inferred.

\section{Lactose malabsorption: reducing substances in stools}

In infants with diarrhoea, unabsorbed lactose in the diarrhoeal stools can be clearly identified by paper chromatography, and a simple test for faecal reducing substances, using Clinitest tablets, is very useful as a screening test to detect unabsorbed lactose in a child with diarrhoea (Kerry \& Anderson, 1964). Demonstration of more than $0.5 \%$ reducing substances in the stools was confirmed to be a valuable screening test by Soeparto et al. (1972) who found stool chromatography useful in diagnosing the type of sugar malabsorption present. They considered that stool $\mathrm{pH}$ was an unreliable screening test for the diagnosis of sugar malabsorption.

\section{Lactose malabsorption: breath tests}

These non-invasive tests are extremely valuable for population screening and for other clinical investigations of carbohydrate digestion. The principle is as follows. Normal mammalian cells do not produce hydrogen in their metabolism. However, many bacteria, including the normal gut flora of virtually all humans, generate $\mathrm{H}_{2}$ if a suitable energy source is presented. Usually when carbohydrate is ingested, absorption is complete in the jejunum, no carbohydrate is presented to the colonic flora, and no extra $\mathrm{H}_{2}$ is produced by colonic bacteria. If unabsorbed carbohydrate, such as lactose, is presented to the colonic flora, then there is a sudden burst of metabolic activity by these bacteria with the production of $\mathrm{H}_{2}$. This gas can be detected and measured in the breath (Metz et al. 1975; Maffei et al. 1976). These $\mathrm{H}_{2}$ breath tests have, generally, replaced the similar tests based on $\left[{ }^{14} \mathrm{C}\right]$ lactose ingestion (Newcomer et al. 1975; Arvanitakis et al. 1977).

\section{Clinical lactose intolerance}

When an oral dose of lactose causes production of flatus, abdominal discomfort or diarrhoea and the ingestion of a similar dose of another carbohydrate does not produce these effects, it can be implied that lactose malabsorption is likely to be present. However, about $10 \%$ of healthy individuals will develop gastrointestinal symptoms, dizziness, nausea and palpitation on ingestion of $50 \mathrm{~g}$ of any carbohydrate, and so it is essential to be cautious in the interpretation of these clinical features. 


\section{CLINICAL FEATURES OF LACTOSE INTOLERANCE}

Adverse reactions which may develop after a lactase-deficient individual ingests lactose in food include nausea, bloating, abdominal pain and diarrhoea. The clinical effects of lactose ingestion are closely related to dose and there is a wide variation among individuals in the dose-response phenomenon. The conventional lactose load used in tolerance tests $(50 \mathrm{~g})$ produces symptoms in $70-80 \%$ of malabsorbers, whereas $10-15 \mathrm{~g}$ lactose, or 0.28 litres milk (0.5 pints), will produce abdominal symptoms in only $30-60 \%$. For example, in a study of twenty subjects known to have low small-bowel lactase levels, doses of lactose ranging from 3 to $96 \mathrm{~g}$ were administered. At $12 \mathrm{~g}$ lactose flatulence; distension, cramps, loose bowel movement or diarrhoea were produced in $75 \%$ of the subjects. Two individuals were symptomatic with as little as $3 \mathrm{~g}$ lactose and none of the twenty subjects had symptoms when equivalent amounts of sucrose or a glucose-galactose mixture were given (Bedine and Bayless, 1973). In a study of hospitalized male patients, $81 \%$ of ninety-eight blacks and $12 \%$ of fifty-nine whites of European extraction, and three of nine nonEuropean whites, had lactose malabsorption based on lactose tolerance tests. Of these lactose-intolerant subjects $72 \%$ had previously realized that milk drinking induced abdominal and bowel symptoms. Skimmed milk $(240 \mathrm{ml})$ produced symptoms in $59 \%$ of forty-four lactose malabsorbers (Bayless et al. 1975).

For reasons that are poorly understood, lactose presented in a food is less likely to induce symptoms than an identical load of lactose presented in solution. One relevant factor may be that the rate of gastric emptying depends on the fat content of the food or drink consumed.

\section{CLINICAL SYNDROMES OF LACTOSE INTOLERANCE}

\section{Modification of milk-drinking habits}

Individuals who are aware of the clinical effects of milk or lactose ingestion modify their dietary habits accordingly. For example Bayless et al. (1975) found milk avoidance to be significantly commoner in lactose-intolerant patients than tolerant patients $(32 \% \mathrm{v} .13 \%)$. In a study of perceived lactose intolerance in doctors we found that the stated milk consumption of those who were milk intolerant was significantly less than the consumption by those not affected by milk (Fowkes \& Ferguson, 1981).

\section{Irritable bowel syndrome}

Since the clinical effects of lactose intolerance are produced by altered gastrointestinal motility, the symptoms produced in some people will suggest a diagnosis of irritable bowel syndrome. In the early literature, lactose intolerance as a cause of irritable bowel syndrome was rather over-reported, and it is now considered that unrecognized lactose intolerance is not a common cause of irritable bowel syndrome (Newcomer \& McGill, 1983; Ferguson et al. 1984). Even when lactase deficiency is present in a patient with irritable bowel syndrome, the two diseases often co-exist and it is appropriate to treat the primary motility disorder by pharmacological or other dietary means (e.g., increase in dietary fibre). However, in a lactase-deficient individual it is important to ensure that the introduction of a high-fibre diet does not also increase the milk content of the diet.

The flatus production associated with lactose malabsorption may cause distress to patients and there are extremely colourful case reports in the literature (Ahmed, 1975; Levitt et al. 1976).

Recurrent abdominal pain in children is almost as common as irritable bowel syndrome. The post-weaning drop in intestinal lactase activity may occur as early as 5 years of age so 
that school children may be intolerant to lactose. A prospective study of recurrent abdominal pain in children in the USA showed malabsorption of lactose in sixteen of fiftynine white children and sixteen of twenty-one non-whites, with $70 \%$ of lactose malabsorbers also having clinical lactose intolerance (Barr et al. 1979). No similar study of non-white children has been published in Britain, but investigation of twenty-six white children in Leeds who presented with recurrent abdominal pain revealed malabsorption of lactose in only three, of whom two developed abdominal pain after taking lactose (Blumenthal et al. 1981). Thus lactose intolerance is mainly relevant in children of ethnic groups with a high prevalence of lactose malabsorption, in whom clinical symptoms may be precipitated by free school milk or similar inappropriate milk consumption (Barr et al. 1979; Blumenthal et al. 1981).

\section{Diarrhoea after gastric surgery}

Gastric surgery, and surgery of the small intestine, radically alter the physiology of the upper gastrointestinal tract. As has been implied previously, the rate of gastric emptying may be relevant to the tolerance or non-tolerance of lactose in a susceptible individual. Thus a lactase-deficient person in whom milk has caused no ill effects before surgery may develop bloating, dumping and diarrhoea post-operatively (Gudmand-Hoyer, 1969; Ferguson et al. 1984).

It is advisable if upper abdominal surgery is to be performed in an individual of a race with a high risk of lactose malabsorption, that the lactase status be defined either before or at the time of surgery. Appropriate advice, to limit the quantity of lactose ingested in the diet, can then be provided to the patient for the post-operative recovery period. Trial and error will soon establish the quantity of lactose tolerated after surgery. It is our experience that lactose intolerance produced by gastric surgery may be crippling, yet eminently treatable, when recognized. Post-vagotomy diarrhoea should never be dismissed by the physician without consideration of lactose intolerance, particularly in a non-white adult.

\section{Multiple pathology}

Since lactose malabsorption is so common, lactose malabsorption and even lactose intolerance will often coexist with other diseases. Since coincident lactose intolerance may modify the pattern of clinical presentation, a period on a lactose-free diet may be of diagnostic value in patients with puzzling combinations of symptoms. For example, some years ago we investigated a 40-year-old Indian doctor with obscure upper abdominal pain. Treatment of his lactose intolerance (by diet) made it abundantly clear that he had two pains, one related to lactose indigestion and the other cardiac in origin. His angina responded to coronary-artery-bypass surgery. Another example is inflammatory bowel disease. Lactose malabsorption will clearly affect faecal volume and gastrointestinal symptoms in patients with Crohn's disease or ulcerative colitis, and it is sensible to establish lactose absorptive capacity in these patients, and if appropriate restrict dietary lactose so that changes in abdominal symptoms can be correlated with activity of disease rather than confused by variations in the pattern of the diet.

\section{Secondary, reversible lactose intolerance}

Disaccharide intolerance may occur as a transient phenomenon associated with a wide variety of diseases of the small intestine in childhood, including gastroenteritis, coeliac disease, giardiasis, protein-energy malnutrition, cows'-milk-protein intolerance, immunodeficiency syndromes and intestinal resections. Currently, World Health Organization (1986) recommendations for management of children recovering from acute diarrhoea are 
that nutrition, including breast feeding, should, in general, be introduced within $24 \mathrm{~h}$. Although many low-lactose and modified milk preparations are now available for nutrition of patients with acute and chronic diarrhoeas, these are likely to be more relevant in the management of immunologically-based milk-protein intolerance, or in chronic diarrhoeal disease, than during acute gastroenteritis.

Lactose intolerance may have other important nutritional implications, particularly in the developing world. For example lactose intolerance was present in high proportions of undernourished African and Indian infants (Chandra et al. 1968; Wharton et al. 1968). Mitchell $e t$ al. (1977) reported the results of a blind controlled trial of a prehydrolysed lowlactose-milk preparation and reconstituted full-cream-milk powder in slightly undernourished Australian aboriginal infants studied in hospital. Infants fed on the lactose hydrolysed milk gained $70 \%$ more weight than those receiving normal milk.

\section{TREATMENT OF LACTOSE INTOLERANCE}

As with other states of food intolerance, the strict diagnosis of lactose intolerance relies on objective measurements of the clinical effects of the withdrawal and re-introduction of lactose. Milk is such an important nutrient that before recommendation of a low-lactose diet, milk intolerance should be formally confirmed by one of the techniques described previously. The only satisfactory treatment of lactose intolerance is a diet with low lactose content (Ferguson et al. 1981). The strictness of the diet depends on the clinical susceptibility of the individual. Patients should be reassured that the symptoms are not due to any disease and can readily be prevented by manipulation of the diet, and indeed that milk and milk products can be used conveniently for their laxative effect. Foodstuffs high in lactose, such as fresh milk, powdered milk, milk puddings should be avoided, but most lactose-intolerant patients can tolerate fermented milk products such as yoghourt (Kolars et al. 1984), and the small amounts of milk used in baking and added to margarines and sausages. If it seems appropriate to use milk products as a protein and calcium source in the diet, then either frequent small quantities of milk can be consumed throughout the day, or substances naturally lower in lactose, such as yoghourts, can be tried.

Lactose-reduced milk and milk products can be prepared in various ways, either by removing lactose or by its hydrolysis using solid-phase bacterial lactases in the manufacturing process. There are now, commercially available, lactase preparations which can be used in the home for hydrolysis of lactose before ingestion of milk etc. Recently, a preparation of bacterially-derived $\beta$-galactosidase has been sold to the public to be ingested in capsule form before consuming lactose containing foods. The effect of this oral enzymereplacement therapy on breath $\mathrm{H}_{2}$ excretion and symptoms after milk ingestion have now been studied in lactase-deficient patients. Only five of sixteen symptomatic patients normalized their breath $\mathrm{H}_{2}$ excretion after $250 \mathrm{mg}$ enzyme and a proportion of patients also had improvement in symptoms of lactose intolerance precipitated by milk (Moskovitz et al. 1987). Nevertheless, even though oral capsules containing bacterially-derived lactase can reduce symptoms of lactose intolerance in some people it is more rational and cost-effective merely to reduce the quantity and modify the nature of lactose-containing products in the diet.

\section{REFERENCES}

Ahmed, H. F. (1975). Irritable-bowel syndrome with lactose intolerance. Lancet ii, 319. American Academy of Allergy and Immunology and National Institute of Allergy and Infectious Diseases (1984). Adverse reactions to foods. National Institutes of Health Publication no. 84-2442. Bethesda, Maryland: US Department of Health and Human Sciences, Public Health Services. 
Antonowicz, I. \& Lebenthal, E. (1977). Development pattern of small intestinal enterokinase and disaccharidase activities in the human fetus. Gastroenterology 72, $1299-1303$.

Arvanitakis, C., Chen, G.-H., Folscroft, J. \& Klotz, A. P. (1977). Lactase deficiency-a comparative study of diagnostic methods. American Journal of Clinical Nutrition 30, 1597-1602.

Atherton, D. J. (1983). Breast feeding and atopic eczema. British Medical Journal 287, 775-776.

Atherton, D. J., Sewell, M., Soothill, J. F. \& Wells, R. S. (1978). A double-blind controlled crossover trial of an antigen-avoidance diet in atopic eczema. Lancet $\mathbf{i}, 401-403$.

Auricchio, S., Rubino, A., Landolt, M., Semenza, G. \& Prader, A. (1963). Isolated intestinal lactase deficiency in the adult. Lancet ii, 324-326.

Axelsson, I., Jakobsson, I., Lindberg, T. \& Benediktsson, B. (1986). Bovine $\beta$-lactoglobulin in the human milk. Acta Paediatrica Scandinavica 75, 702-707.

Barnetson, R. StC. (1980). Hyperimmunoglobulinaemia $\mathrm{E}$ in atopic eczema (atopic dermatitis) is associated with 'food allergy'. Acta Dermatovenereologia (Stockholm) Suppl., 92, 94-96.

Barnetson, R. StC. \& Lessof, M. H. (1983). Challenges to medical orthodoxy. In Clinical Reactions to Foods, pp. 15-34 [M. H. Lessof, editor]. Chichester: John Wiley.

Barnetson, R. StC., Merrett, T. G. \& Ferguson, A. (1981). Studies on hyperimmunoglobulinaemia E in atopic diseases with particular reference to food allergens. Clinical and Experimental Immunology 46, 54-60.

Barr, R. G., Levine, M. D. \& Watkins, J. B. (1979). Recurrent abdominal pain of childhood due to lactose intolerance. New England Journal of Medicine 300, 1449-1452.

Bayless, T. M., Rothfield, B., Massa, C., Wise, L., Paige, D. \& Bedine, M. S. (1975). Lactose and milk intolerance: clinical implications. New England Journal of Medicine 292, 1156-1160.

Bedine, M. S. \& Bayless, T. M. (1973). Intolerance of small amounts of lactose by individuals with low lactase levels. Gastroenterology 65, 735-743.

Bleumink, E. \& Young, E. (1968). Identification of the atopic allergen in cows' milk. International Archives of Allergy 34, 521-543.

Blumenthal, I., Kelleher, J. \& Littlewood, J. M. (1981). Recurrent abdominal pain and lactose intolerance in childhood. British Medical Journal 282, 2013-2014.

Burr, M. L. \& Merrett, T. G. (1983). Food intolerance: a community survey. British Journal of Nutrition 49 , 217-219.

Cant, A., Marsden, R. A. \& Kilshaw, P. J. (1985). Egg and cows' milk hypersensitivity in exclusively breast fed infants with eczema, and detection of egg protein in breast milk. British Medical Journal 291, 932-935.

Chandra, R. K., Pawa, R. R. \& Ghai, O. P. (1968). Sugar intolerance in malnourished infants and children. British Medical Journal 4, 611-613.

Commission of the European Communities. (1980). Food-science and techniques. Sensitivity of individuals to food components and food additives. Reports of the Scientific Committee for Food, Ser. 12, EUR 7823. Luxembourg: Office for Official Publications of the European Communities.

Cucchiara, S., De Ritis, G., Follo, D., Jaccarino, E., Romaniello, G., Latte, F., Staiano, A. \& Auricchio, S. (1983). Cow's milk protein intolerance (CMPI): evaluation of clinical, histological, endoscopic and laboratory criteria for postchallenge diagnosis. Italian Journal of Gastroenterology 15, 231-235.

Ferguson, A. (1987). Models of immunologically driven small intestinal damage. In Immunopathology of the Small Intestine, pp. 225-252 [M. N. Marsh, editor]. Chichester: John Wiley.

Ferguson, A., Allan, F. \& Al Thamery, D. (1980). Functional maturity of villus enterocytes in states of accelerated cell turnover without villus atrophy. In Cell Proliferation in the Gastrointestinal Tract, pp. 343--349 [D. Appleton, J. P. Sunter and A. Watson, editors]. Tunbridge Wells: Pitman Medical.

Ferguson, A., Macdonald, D. M. \& Brydon, G. W. (1984). Prevalence of lactase deficiency in British adults. Gut 25, 163-167.

Ferguson, A. \& Maxwell, J. D. (1967). Genetic aetiology of lactose intolerance. Lancet ii, 188-191.

Ferguson, A., Paul, G. \& Snodgrass, D. R. (1981). Lactose tolerance in lambs with rotavirus diarrhoea. Gut 22, $114-119$.

Firer, M. A., Hosking, C. S. \& Hill, D. J. (1981). Effect of antigen load on development of milk antibodies in infants allergic to milk. British Medical Journal 283, 693-696.

Flatz, G. (1984). Gene-dosage effect on intestinal lactase activity demonstrated in vivo. American Journal of Human Genetics 36, 306-310.

Fontaine, J. L. \& Navarro, J. (1975). Small intestinal biopsy in cow's milk protein allergy in infancy. Archives of Disease in Childhood 50, 357-362.

Fowkes, F. G. R. \& Ferguson, A. (1981). Self-diagnosed irritable bowel syndrome and milk intolerance in white and non-white doctors. Scottish Medical Journal 26, 41-44.

Galant, S. P., Franz, M. L., Walker, P., Wells, I. D. \& Lundak, R. L. (1977). A potential diagnostic method for food allergy: clinical application and immunogenicity evaluation of an elemental diet. American Journal of Clinical Nutrition 30, 512-516.

Goldman, A. S., Anderson, D. W., Sellars, W. A., Saperstein, S., Kniker, W. T. \& Halpern, S. R. (1963). Milk allergy. 1. Oral challenge with milk and isolated milk proteins in allergic children. Pediatrics 32, $425-443$.

Granati, B., Marioni, L. \& Rubaltelli, F. F. (1985). Evaluation with guinea pigs of the allergenic capacity of two infant formulae based on hydrolyzed milk proteins. Biology of the Neonate 48, 122-124. 
Granato, D. A. \& Piguet, P. F. (1986). A mouse monoclonal IgE antibody anti bovine milk $\beta$-lactoglobulin allows studies of allergy in the gastrointestinal tract. Clinical and Experimental Immunology 63, 703-710.

Gudmand-Hoyer, E. (1969). Lactose malabsorption in patients operated upon for peptic ulcer. Scandinavian Journal of Gastroenterology 4, 705-711.

Harrison, M., Kilby, A., Walker-Smith, J. A., France, N. E. \& Wood, C. B. S. (1976). Cows' milk protein intolerance: a possible association with gastroenteritis, lactose intolerance, and IgA deficiency. British Medical Journal i, 1501-1504.

Hattevig, G., Kjellman, B. \& Bjorksten, B. (1987). Clinical symptoms and IgE responses to common food proteins and inhalants in the first 7 years of life. Clinical Allergy 17, 571-578.

Hattevig, G., Kjellman, B., Johansson, S. G. O.\& Bjorksten, B. (1984). Clinical symptoms and IgE responses to common food proteins in atopic and healthy children. Clinical Allergy 14, 551-559.

Hoj, L., Osterballe, O., Bundgaard, A., Weeke, B. \& Weiss, M. (1981). A double-blind controlled trial of elemental diet in severe, perennial asthma. Allergy 36, 257-262.

Iyngkaran, N., Davis, K., Robinson, M.J., Boey, C. G., Sumithran, E., Yadav, M., Lam, S. K. \& Puthucheary, S. D. (1979). Cows' milk protein-sensitive enteropathy. Archives of Disease in Childhood 54, 39-43.

Jakobsson, I. \& Lindberg, T. (1978). Cow's milk as a cause of infantile colic in breast-fed infants. Lancet ii, 437-440.

Jarrett, E. E. E. (1977). Activation of IgE regulatory mechanisms by transmucosal absorption of antigen. Lancet ii, 223-225.

Jenkins, H. R., Pincott, J. R., Soothill, J. F., Milla, P. J. \& Harries, J. T. (1984). Food allergy: the major cause of infantile colitis. Archives of Disease in Childhood 59, 326-329.

Kerry, K. R. \& Anderson, C. M. (1964). A ward test for sugar in faeces. Lancet i, 981.

Kilshaw, P. J., Heppell, L. M. J. \& Ford, J. E. (1982). Effects of heat treatment of cows' milk and whey on the nutritional quality and antigenic properties. Archives of Disease in Childhood 57, 842-847.

Kolars, J. C., Levitt, M. D., Aouji, M. \& Savaiano, D. A. (1984). Yogurt-an autodigesting source of lactose. New England Journal of Medicine 310, 1-3.

Kuitunen, P., Visakorpi, J. K., Savilahti, E. \& Pelkonen, P. (1975). Malabsorption syndrome with cow's milk intolerance. Clinical findings and course in 54 cases. Archives of Disease in Childhood 50, 351-356.

Lacroix, B., Kedinger, M., Simon-Assmann, P. \& Haffen, K. (1984). Early organogenesis of human small intestine: scanning electron microscopy and brush border enzymology. Gut 25, 925-930.

Lebenthal, E. (1975). Cow's milk protein allergy. Pediatric Clinics of North America 22, 827-833.

Levitt, M. D., Lasser, R. B., Schwartz, J. S. \& Bond, J. H. (1976). Studies of a flatulent patient. New England Journal of Medicine 295, 260-262.

Lund, E. K., Bruce, M. G., Smith, M. W. \& Ferguson, A. (1986). Selective effects of graft versus host reaction on disaccharidase expression by mouse jejunal enterocytes. Clinical Science 71, 189-198.

McCalla, R., Savilahti, E., Perkkio, M., Kuitunen, P. \& Backman, A. (1980). Morphology of the jejunum in children with eczema due to food allergy. Allergy 35, 563-571.

McLaughlan, P., Anderson, K. J. \& Coombs, R. R. A. (1981 a). An oral screening procedure to determine the sensitising capacity of infant feeding formulae. Clinical Allergy 11, 311-318.

McLaughlan, P., Anderson, K. J., Widdowson, E. M. \& Coombs, R. R. A. (1981 b). Effect of heat treatment on the anaphylactic sensitising capacity of cows' milk, goats' milk, and various infant formulae fed to guinea pigs. Archives of Disease in Childhood 56, 165-171.

Maffei, H. V. L., Metz, G. L. \& Jenkins, D. J. A. (1976). Hydrogen breath test: adaptation of a simple technique to infants and children. Lancet $\mathbf{i}, 1110-1111$.

Manuel, P. D., Walker-Smith, J. A. \& Soeparto, P. (1980). Cow's milk sensitive enteropathy in Indonesian infants. Lancet ii, 1365-1366.

May, C. D. (1986). Defined versus ill-defined syndromes associated with food sensitivity. Journal of Allergy and Clinical Immunology Suppl. 78, 144-148.

May, C. D., Remigio, L., Feldman, J., Bock, S. A. \& Carr, R. I. (1977). A study of serum antibodies to isolated milk proteins and ovalbumin in infants and children. Clinical Allergy 7, 583-595.

Metcalfe, B. D. (ed.) (1986). Symposium Proceedings on adverse reactions to food and food additives. Journal of Allergy and Clinical Immunology 78, Suppl.

Metz, G. L., Jenkins, D. J. A., Peters, T. J., Newman, A. \& Blendis, L. M. (1975). Breath hydrogen as a diagnostic method for hypolactasia. Lancet i, 1155.

Michael, J. G., Muckerheide, A., Dosa, S. \& Pesce, A. J. (1981). Modulation of immune responses by antigenic fragments. In The Immune System, vol. 2, p. 284 [C. M. Steinberg and I. Lefkowitz, editors]. Basel: Karger.

Milla, P. J. (1984). Milk sensitive colitis in infants. Advanced Medicine 20, 39-47.

Mitchell, J. D., Brand, J. \& Halbisch, J. (1977). Weight-gain inhibition by lactose in Australian aboriginal children. A controlled trial of normal and lactose hydrolysed milk. Lancet $\mathbf{i}, 500-502$.

Moskovitz, M., Curtis, C. \& Gavaler, J. (1987). Does oral enzyme replacement therapy reverse intestinal lactose malabsorption? American Journal of Gastroenterology 82, 632-635.

Newcomer, A. D. \& McGill, D. B. (1983). Irritable bowel syndrome. Role of lactase deficiency. Mayo Clinic Proceedings 58, 339-341. 
Newcomer, A. D., McGill, D. B., Thomas, P. J. \& Hofmann, A. F. (1975). Prospective comparison of indirect methods for detecting lactase deficiency. New England Journal of Medicine 293, 1232-1236.

Nordstrom, C. \& Dahlquist, A. (1973). Quantitative distribution of some enzymes along the villi and crypts of human small intestine. Scandinavian Joumal of Gastroenterology 8, 407-416.

Pahud, J.-J., Monti, J. C. \& Jost, R. (1985). Allergenicity of whey protein: its modification by tryptic in vitro hydrolysis of the protein. Journal of Pediatric Gastroenterology and Nutrition 4, 408-413.

Perdue, M. H., Chung, M. \& Gall, D. G. (1984). Effect of intestinal anaphylaxis on gut function in the rat. Gastroenterology 86, 391-397.

Perkkio, M. (1980). Immunohistochemical study of intestinal biopsies from children with atopic eczema due to food allergy. Allergy 35, 573-580.

Poulsen, O. M., Hau, J. \& Kollerup, J. (1987). Effect of homogenization and pasteurization on the allergenicity of bovine milk analysed by a murine anaphylactic shock model. Clinical Allergy 17, 449-458.

Rey, J., Schmitz, J., Rey, F. \& Jos, J. (1971). Cellular differentiation and enzymatic deficits. Lancet ii, 218.

Royal College of Physicians and the British Nutrition Foundation (Joint Report) (1984). Food intolerance and food aversion. Journal of the Royal College of Physicians of London 18, 83-123.

Sahi, T., Isokoski, J., Jussila, J., Launiala, K. \& Pyorala, K. (1973). Recessive inheritance of adult-type lactose malabsorption. Lancet ii, 823-826.

Sahi, T. \& Launiala, K. (1977). More evidence for the recessive inheritance of selective adult type lactose malabsorption. Lancet ii, 823-826.

Schwartz, H. R., Nerurkar, L. S., Spies, J. R. \& Scanlon, R. T. (1980). Milk hypersensitivity: RAST studies using new antigens generated by pepsin hydrolysis of beta-lactoglobulin. Annals of Allergy 45, 242-245.

Simoons, F. J., Johnson, J, D. \& Kretchmer, N. (1977). Perspective on milk-drinking and malabsorption of lactose. Pediatrics 59, 98-109.

Soeparto, P., Stobo, E. A. \& Walker-Smith, J. A. (1972). Role of chemical examination of the stool in diagnosis of sugar malabsorption in children. Archives of Disease in Childhood 47, 56-61.

Spies, J. R. (1971). New antigens in lactose (35546). Proceedings of the Society for Experimental Biology and Medicine 137, $211-214$.

Sumithran, E. \& lyngkaran, N. (1977). Is jejunal biopsy really necessary in cow's milk protein intolerance? Lancet ii, $1122-1124$.

Van Sickle, G. J., Powell, G. K., McDonald, P. J. \& Goldblum, R. M. (1985). Milk- and soy protein-induced enterocolitis: evidence for lymphocyte sensitisation to specific food proteins. Gastroenterology 88, $1915-1921$.

Walker-Smith, J. (1975). Cow's milk protein intolerance. Transient food intolerance of infancy. Archives of Disease in Childhood 50, 347-350.

Weaver, L. T., Flaker, M. F. \& Nelson, R. (1986). Neonatal intestinal lactase activity. Archives of Disease in Childhood 61, 896-899.

Wharton, B., Howells, G. \& Phillips, I. (1968). Diarrhoea in Kwashiorkor. British Medical Journal 4, $608-613$.

Wilson, N. \& Silverman, M. (1985). Diagnosis of food sensitivity in childhood asthma. Journal of the Royal Society of Medicine Suppl. 5, 11-16.

World Health Organization (1986). Diarrhoeal Diseases Control. Review no. 1. Geneva: WHO. 